\title{
The Nexus Between Causes of Boko Haramand its Effect on Nigeria Economy
}

\author{
Ukauwa, Ezechimerem Ephraim \\ Department of Economics \\ Abuja University \\ Bilal Celik \\ Department of Economics \\ Nile University of Nigeria \\ Gylych Jelilov \\ Department of Economics \\ Nile University of Nigeria \\ Natalia Olali \\ Department of Mathematics \\ University of Niger Delta
}

\begin{abstract}
The study on the nexus between Boko Haram, causes and its effect on Nigeria economy examines the causes of Boko Haram and its effect on Nigeria economy. In as much as poverty is acclaimed to be major cause of Boko Haram, its progenitors capitalized on it to fan the embers of its recruitment thereby deriding Nigeria's economy. The recruitment of the youthful population was for them to see that they have magic wand for their emancipation. However, the analysis of various economic indices is seen to lean heavily on other indicators which aid the recruitment drive of Boko Haram against the state. The disaggregation of various economic indicators has also tilted towards other factors aside poverty as the reason for terrorism. The period of boom in Nigeria economy was mismanaged which wasfuelled by the trajectory of successive misrule over the years which also failed to put in place structures for economic growth. These theories are examined as we employ qualitative and descriptive research approach to understand the nexus between the causes of Boko Haram and its effect on Nigeria economy. The study explored various theories and theoretical discussin the literature in this regard. The study discovers that causes of Boko haram are multivariate and their effect includes ideology, Islamic fundamentalism, economic, social, poverty and religious bigotry.The result of the research reveals that ideology and religious fundamentalism are sine qua non to the effect by Boko Haram destructive tendencies against Nigeria state and central to the movement's long existence.The paper therefore recommends among others reorientation of the youth, empowerment of the impoverished and synergy among the security agencies.
\end{abstract}

Keywords: terrorism, boko haram, economic growth, Nigeria

\section{Introduction}

\subsection{Background of the study}

When a group wages a psychological war and uses it to hoodwink its followers while using the product of the civilization it is against, tells a different story. This assertion is true of the group popularly called Boko Haram interpreted as 'western education is forbidden'while the organization is known in Islamic parlance as Jama'atulAhlusSunnah Lid daawatiwal Jihad. This group emerged as a religious group with political undertone with more concentration on preaching in Islamic way displaying an aura of charity amongst the less privileged. These were happening at the northeast flank of the country with its base at Borno State. The activities of the group changed in 2009 after the Nigerian government crackdown on its followers as a result of which its spiritual and political leader Muhammad Yusuf was killed.

Imperatively, Boko Haram story begins with a preacher named Mohammed Marwa; born in 1927 whomoved to Kano, a town in northern Nigeria where he began a career as a preacher. His sermons were extreme and often bizarre when compared with the tenets of Islamic religion. He vehemently preached against western culture and its popularity in Nigeria. Observers named him Maitatsine which is translated'the one damned'. 
He further abhorred and criminalized reading any other book such ashadiths or sunnah, other than the Qur'an. He saw as sinful and a sign of paganism any practice that emanates from any book other the Qur'an and even came close to declare himself as the true prophet in the place of the founder of the Islamic religion (Ford, 2014).

The MaitatsineIslamic movement, which emerged in 1980, was ignored by Nigeria's political leaderswho did not see any threat in the movement's sermon even when it was noticedthat there was increase in anti-governmentmessages and followership. Heinstigated uprising against the government which created descent into civil disobedience. The force used to confront the uprising by the military government at the time, recorded high casualty with the death of their leader, Mohammed Marwa. This brought the end of Maitatsine. With the extinct of Maitatsine, other Islamic distortions were had then entered the Islamic state in west Africa officially known as Jama atuAhlussunnahLidda awatiWal Jihad emerged which is known in local parlance as Boko Haram which emanated from the teaching of its founder Sheikh Mohammad Yusuf in early 2007 who vehemently taught his followers to resist western education.

Boko Haram as established by the late founder Shiekh Mohammad Yusufstarted as a subtle harmless monthly preacher in Borno state, in a far end of Nigeria's northeast geo-political zone, gained attraction among the youth that finally formed the bulwark of the movement. By the time government came to term with its subtlety, it has turned into security challenge. Never has the nation known such a dastardly movement that is deviant, anti-government and ant-authority (Adage et al, 2012). At the inception of the movement, it was involved mostly in sectarian violence that saw Christians as its main targets for maiming and killing using clubs machetes and small arms. However, its attack has gained sophistication overtime as its destructive activities have engulfed the whole region with its extension into the hinterland of the country with increased casualties both in human and material. The onslaught increased in sophistication with the use of improvised explosive device (IED) to its arsenal of destruction. Government and international structures which include United Nations office, Nigeria Police Force headquarters, Plaza/Nyanya and Independence Daybombing, all in the Federal Capital City, Abuja, were not spared. The sect's training from AL Qaeda in the Islamic Maghreb in the North Africa or from Al-shabab in Somalia, added credence to the fact of international assistance to the terrorists. All these increased with the Muslim fundamentalist sect, bombing innocent people, women and children who had no idea of what it is fighting for. Connivance and collusion with official personnel especially the elite in the northern zones of the countryhave made the war with Boko Haram intractable (Blanchard, 2014).

After the 2009 uprising, the activities of the sect were slow. The violence of the group re-emerged in 2010 with new tactics which include other attributes of terrorism such as bombing, kidnapping, and attacking Islamic clerics, Mosques and churches in the country. Nigeria witnessed the first suicide bombings in police headquarters and United Nation's office in Abuja (Blanchard, 2014). To add to the fray, 250 female students from Government Girl's Secondary school Chibok in Borno State were on 14th April, 2014 (Zenn, 2014). Activities of Boko Haram gained international attention as it was designated as Foreign Terrorist Organization (FTO) by the United State Security Department in November 2013 while The United Nation listed Boko Haram as an affiliate of Al-Qaeda also as an organisation of Al-Qaeda in the Islamic Maghreb (AQIM) (Reuters, 2014).

It is a known fact that the ideology of Boko Haram is mainly against Western education andto establish extremist religious practice in Nigeria. It is also a common practice of Taliban in Afghanistan to use Islam as a tool of oppression and intimidation within its political territory,establish their kind of worship which they termed pure and sharia judicial system. This is the order Boko Haram has etched in its operation. Its killing spree is unabated. However, the political colouring of the movement and lack of political will to address the movement has continued to fuel the group opportunity to cause mayhem in the system.

High level of insecurity has persisted in the country which Boko Haram and other militia group operationshave continued to manifest in the northern zone of the country. It is a fact that insecurityis a threat to any willing investor and business endeavours. It is a waste to invest in an insecure environment. Business owners would not bear the risk of security uncertainty with regards to their investments especially. Insecurity is not one of the risks any potential investor would like to bear due to the unquantifiable cost, both material and human resources, and loss occasioned by the insurgency and political miscalculation in the nation.

\section{Section Two: Literature Review}

\subsection{Theoretical Framework}

Theories are guideposts in all fields of learning. These alienate one from guess and human errors and subjectivity. Theories lie on facts rather than mere experience, guesswork or speculations but derived from scientific research, which lie within the intended direction (Onah, 2003). From the foregoing, conflict theory is selected as the theory for the study. 
Conflict is common in organizations or where two or more persons associate to achieve certain objectives. Ugwu (2000) succinctly defined conflict as act of striking together, mutual interference of opposing or incompatible forces, ideas, interest contest, and discord among different persons. Conflict dispute and struggle against persons withopposing views or claims. Conflict is also believed to represent a condition of disagreement within interests by parties with divers understanding (Imobighe, 2003). Though, conflict is referred as contradictions which manifests through behaviours, phenomenon, perception and tendencies.Nnoli (2003) andMialli (1992), assert that conflict results from views as extremely important while Afegbua (2010) states that as behaviouralpattern, conflict involves inter-personal, inter-groups, inter-organizations and inter-states.

Dhrendorf (1959)describes the concept of conflict as a basic factor underlying societal dynamics such that all participants are interested in self-gain. Anugwom (1997) posits that conflict in the industrialization process is the quest for self-gains and conflict in the process is due to variance of interest between management and labour.This theory therefore emphasizes management interest as profit while labouris for wages. He maintains that this phenomenon creates possessive tendency amongst the two as each tries to maintain its dominance with this argument. Boko Haram which currently rampaging over the northeast geo-political zone can be said to have emerged as the few elitemuzzles up the majority downtrodden, while the downtrodden respond with what they know best against the elite, restiveness. This theory becomes relevant as each tries to dominate its avowed space and insecurity ensues.

\subsection{The Concept of Terrorism}

Richards (2014) concept of terrorism is"Terrorism is the use of violence or the threat of violence with the primary purpose of generating a psychological impact beyond the immediate victims or object of attack for a political motive". Though, the concept of terrorism has no universal accepted definition, but scholars have continued to investigatethe definitions as some make their preference over others while the need for real definition of terrorism remains elusive. A more encompassing definition would include such factors as role of the individual, groups and state actors, nature and type of terrorist as it could be selective, random or suicidal.Though, used in a derogatory form during hate speech but when used, depicts violence and an act by either people or conduct of violence. Succinctly, Sanchez-Cuenca(2014) gave the definition of terrorism which is accepted by dominant school as any violence against non-combatants whileSchmid (2004) sees terrorism in five climes viz: crime; politics; warfare; communication; religious fundamentalism. Hence, it is illegal, illegitimate, has political undertone, used as an instrument of political strategyand coercion but condemnable in the comity of nations. Terrorism in a world view connotes evil, religiously motivated as we can see in the northeast region of Nigeria National. It aims to generate fear beyond the immediate target audience and to increase the power capability of the group undertaking it. (Lutz and Lutz, 2004).

Terrorism flows from conceptualizing it, applies it to disrupt peaceful coexistence of peaceful population in a society and bring about forced change in societal values and influence political calculation such as Brotherhood political party in Egyptbefore the current leadership came in place (Brinkel and Aithida, 2012).Terrorism hinders and also truncates democratic peaceful process (Clapman, 2003). Its objectives also include enforcing change in leadership and government policies, annexing boundaries and declaring independent state and threatening the status quo (Lutz and Lutz, 2006).Therefore, terroristsuse of violence and intimidation to cause collateral damage and coerce the government to concede to weird demands.

\subsection{Trends in Modern Terrorism}

A number of factors have been put forward for the resort to and rise in terrorist activities.

a) Terrorists use unconventional methods which include suicide bombing, assassinations, and recently kidnapping as they are not able to march the government's weapons.

b) Availability of soft spots to attack.

c) The terrorists are made prominent through mass media such as radio and television.

d) Weapons with technology based are currently manufactured which aids terrorism.

Schmid (2013) argues that terroriststwo main targets are the state and states institutions, and civilian population which is used as negotiating instruments for arms and funding.

Terrorist are quick to adapt to new trends and networks for fragmented leadership and ubiquitous nature attacks. These make them disarticulated and unable to holed-up at a spot. From the initial terrorist attack in 70s to $9 / 11$ attacks in USA, violence as occasioned by the terrorists and their religious fundamentalists and jihadist threat is in the increase targeting indiscriminately and creating large numbers of casualties and collateral damage. Terrorist attacks today have become more and more indiscriminate for want of multiple damages as its organization pattern is disaggregated into an organization, as a network and or a social movement(Comas et al, 2015; Rapport, 2003; Sanchez-Cuenca, 2014; Walter Laquer, 1999 and Alapiki, 2015). 


\subsection{Causes of Terrorism}

The causes of terrorism world-wide can be said to be multifaceted. This is why the causes cannot be captioned in a sentence. The causes take different dimensions with regards to the individuals or organizations that are pursuing the agenda. However, the causes range from religion firstly, which perpetrators have continued to use as a cover to unleash horrendous damages to humanity and the environment. All the time religion was used to ferment terrorist attacks, it was and still being used in a subtle way to hoodwink the ignorant of their target but later use it to force the government to concede to their request by pleading purity ofreligion (Lutz and Lutz, 2004). However, lately, recruitment of adherents is among the poor and those at the lower social strata of the society, attraction is now made of adherents' poverty level, unemployment status, state of illiteracy among others(Berrebi and Klor, 2012).

It is a known fact that globalization and free trade have succeeded in spreading the good, the bad and the ugly products round the world including terrorism. Hence, Williams (2008) directs his focus on globalization stating that the old age of terrorism and its adverse effect notwithstanding, non-state actors now have access to flow of arms at a large scale even to negotiate with organized governments. This is further made easier for the terrorists with the economic downturn of nations which also propels them to challenge authorities and receive converts as they capitalize on the impoverished populace (as cited in Adams and Ogbonnaya, 2014).

Hoffmann (2002) also maintains that globalization has contributed in no small measure in fuelling inequalities and violencefactor by creating inequalities within and among states. These inequalitiesfuel frustrations within states which often resort to violence. This is made worse with discrimination against access to public health, education employment opportunities and other social services while grievances are directed against the state through violence (Piazza, 2011).Fragmented society cannot foster enough unity to demobilize any incident that tantamount to destroy its fledging unity. Consequently, the differences occasioned by disconnect between social groups, religion, culture, income status would lead to yawning gap with respect to interrelationship which aggravates terrorism and make an accepted way of life for many (Ozdogan, 2008 and Bjorgo, 2005).

The central factor that fuel terrorism is the ability to maintain poverty and create a situation of economic deprivation among the larger population where the fighters would be recruited. Gurr (1970) came up with the relative deprivation explanation for the causes of terrorism. Relative deprivation argument is domiciled between what an individual expects and what he gets from the economic distributive process which makeshim to him to resort to violence as the last resort. This postulation is such because the deprived would find it easier to engage in terrorism being frustrated and has nothing at stake (Krieger and Meirrieks, 2011). Also, it is common to see inflation in the countries withterrorist-caused Internally Displaced Persons (IDPs)experiencing more suicide terrorism attacks in order to get back to the society that has deprived them accommodation (Choi and Piazza, 2014). This is common knowledge since the inception of the insurgency in Nigeria in 2007.

\subsection{BokoHaramand Theory of Poverty}

Foreigners and non-indigenes are the main investor in any economy hence attracting these groups of people has been the mantra of ant government. This is done by creating enabling environment by way of one-stop-shop, tax holiday, and security and provision right infrastructure for easy business. However, over the life span of Boko Haram insurgency, this business initiative has suffered. Hence, the business environment has been badly assaulted given rise to negative trade balance in the region. Some, who could no longer endue the effect of the insurgency, gathered what remainedof their businesses and investments, under this circumstance, and relocated thereby dealing a deadly blow on the economy. Also, commercial banks activities crashed as relocation ensued and business hours reduced. Interstate trading reduced while inventory of goods stockpiled due to insecurity vices(Obumneme, 2012).

In the event of all these, poverty became glaring. Liolio (2013) infers that economic status of the populace has fuelled recruitment into Boko Haram camp which is also aggravated by illiteracy, ineptitude, corruption, discrimination and alienation to civilization, modernization and globalization that has engendered poverty in many underdeveloped countries and encouraged recruitment of terrorists. Also, he states that insurgency route is aggravated by grievances, socioeconomic and political problems which are bedfellows of underdeveloped countries and countries engulfed with by corrupt regime, segregation and social imbalance of economic resources. Scholars like Adesoji (2010) stress thatmarginalization in Nigeria and imbalance distribution of resources gave rise to Boko Haram insurgency. These attendant frightful cases, daily erode the confidence of the citizenry for bright future. In such a case, most of these unemployed youths are the primary target of the insurgents. The International Fund for Agricultural Development, IFAD (2007) and Adebayo (2014) accede to the vicious cycle of poverty theory. At the bedrock of poverty legacieseconomic stagnation, unemployment, uneven economic development,illiteracy, discrimination, and economic marginalization arefertile ground on which terrorist seed andrecruitment can flourish (Andenrele, 2014; Blanchard, 2014; Umar, 2013; Hensenclever\&Rittberger, 2005 and Ojolo, 2013). 
Boko Haram threat has maintained doubt on the security system, corporate and political existence of Nigeria (Zenn, 2014). Anyadike (2014), Umar (2012) and Nossiter (2011) have alluded to the fact that Boko Haram unabated attacks is not exclusive preserve of indigenes only but also, to a large extent, has unleashed constant attacks, suicide bombing and kidnapping on foreigners alike. These actions and deprivation have increased poverty rate in the already impoverished region (NBS, 2012).

\section{Section Three: Research Methodology}

Theresearch employs qualitative method using descriptive analytic approach. This approach refers to identifying, analysing and reporting patterns of data collected (Braun and Clarke, 2006). Research methodology allows proper analysis and evaluation by the researcher and other users (Kothari, 2004).Research method is in three parts namely:

a) Process of collection of data,

b) Process of establishing relationships

c) Evaluation of the results obtained and their accuracy.

These are the processes research methodology constitutes (Kothari, 2004). Subjecting certain political, economic or social issues to qualitative analysis has psychological and leadership influence.It is a known fact that quantitative methodology is not the adequate tool to address changing social order hence, since value judgements aspect of social science requires comparison, therefore, qualitative methodology of analysis becomes the required analysis method (King et al, 1994).The empirical analysis data of this research relies on secondary data and the use of descriptive analysis.

\section{Section Four: Result Interpretation and Presentation}

Lethal conflicts requires large amount of human and material resources to address civil wars, revolutions, terrorism, genocides, interstate wars, religious, linguistic, and ethnic conflicts. Armstrong (2005) notes and looks at fundamentalism not to be equated with religious conservatism: second, it should not be linked automatically with violence: third, it is not an exclusive Islamic phenomenon which could be found in all the religions - Christianity, Judaism, and Hinduism. He also further sees fundamentalism as when there is a revolt against modern secular society(Armstrong, 2005). Fundamentalism can follow descriptive and evaluative concept like other political concept. The emergence of Boko Haram insurgency has been attributed to poverty, inequality, economic dislocation and disequilibrium, injustice and lack of civil liberty by political and opinion at different strata of the society. In as much as socio-religious and political inadequacies are the causes of Boko Haram insurgency, without addressing security and poverty level in the affected region in a sustainable manner, it will be almost impossible to defeat Boko Haram.

Poverty is the inability of individual to have the basic necessities of life such as clothing, food, education, shelter, and healthcare characterized by unemployment, lack of social amenities such as electricity, and water. The United Nations statement on poverty issued in 1998 and signed by the heads of all UN agencies opines, "Fundamentally poverty is a denial of choices and opportunities, a violation of human dignity. It means lack of basic capacity to participate effectively in society. It means not having enough to feed and clothe a family, not having a school or clinic to go,not having the land on which to grow one's food or a job to earn one's living, not having access to credit. It means insecurity, powerlessness and exclusion of individuals, households, and communities. It means susceptibility to violence, and it often implies living on marginal or fragile environments, without access to clean water or sanitation" (un.org).

NBS Report (2010), states that socio-economic conditions of Nigerians between 1980 and 2010 increased negatively. While 6.2per cent were living in extreme poverty in 1980, the figure increased to a record of 38.7per cent in 2010 even when oil revenue increased during the period. The extremely and moderately poor were put at 38.7 per cent and 30.3 per cent respectively, while non-poor was put at 31 per cent.

The report further stressed that about 100 million Nigerians were earning less than one dollar (\$1) a day in 2010 which means in an estimated population of 163 million Nigerians, 112.47 million Nigerians were living below poverty line.

\section{Section Five: Conclusions and Recommendation}

\section{Conclusions}

This study has shown that poverty could not be the only cause of Boko Haram insurgency, though it could be a necessary factor. It is also a known fact,but not sufficient to aver why BokoHaram evolved into a terrorist organization as political angle of the discuss has dominated other reasons. Hence, we disagree with Gurr's theory andKrueger position of poverty and lack of civil liberties respectivelyas the reason for Boko Haram insurgency and major causes of terrorism. From the foregoing, there is no 'cure all' or 'cause all'theory that could explain Boko Haram terrorism. There are several terrorist organizations in the world today manned and populated by influential and children of the wealthy. 
To maintain terrorist movement, there must be individuals that bankroll the expenses. Generally, fundamentalism and ideology are the main rallying point for Boko Haram insurgency.

Boko Haram ideology is rooted in Islam which holds the Koran as the golden rule of man's existence rejecting every other rule in the system. Having demonstrated the influence of fundamentalism and ideology, and larger-than-life role that politics play in evolvement of the insurgent groups, there has not been enough monitoring of the ideologies which these groups capitalize on before they exit to create caliphates. It is also glaring to see that insurgent operations have always taken to challenge democratic governments knowing that military government would not accommodate such effrontery.

The study establishes that the national ideology is in variance with the ideology of the insurgents as the name applies, Boko Haram (western education is evil) even when the national government is spending huge national resources to bring different geo-political regions in the northern Nigeria at par with their southern counterpart. Hence, it is conflict of ideologies that are worlds apart. Succinctly put, Juergensmeyer (2000) opines that "an act of terrorism usually implies an underlying power and legitimizing ideology". The enforcement of Boko Haram ideology on the populace at its catchment area by force and not by moral-suasion, has implication on the political conflict that is currently ravaging the country. However, poverty, injustice and lack of civil libertiesare seen to be appendages and facilitators of the central force of fundamentalism and ideology in the Boko Haram preaching.

Economic downturn of the nation is attributable to the economic losses in the affected zones due to dislocation of businesses and investments that had to be moved out completely or destroyed by the insurgents' activities. National resources that are to be used to enhance economic activities in other geo-political regions are harnessed and sent to the insurgent-prone areas to acquire arms, ammunition and other military hardware. The mass movement of people away from these areas has also created congestion at the urban centres and misuse of public amenities and infrastructures can only be imagined. Sanitation and upkeep of the internally displaced persons (IDPs)have suddenly become humanitarian emergency situation.

\section{Recommendations}

a) That national patriotism among the visual, audio and print media should be considered in reporting activities of Boko Haram to giving them undue publicity which fuels their ego.

b) Information sharing among the security agents both within Nigeria and neighbouring countriesshould be enhanced to prevent cross-border escape and spread of their mayhem.

c) Empower and engage the youths both in school and at work to prevent them from being recruited as suicide bombers and child-soldier.

d) To strictly maintainsecurity at the borders that would restrict unguarded influx of immigrants, easy escape insurgents and to apprehend weapons trader, and prevent support from sister Islamicorganizations like Al-shabab.

e) Example should be made of arrested insurgents by successfully prosecuting them to serve as a deterrent to those that would like to toe the same line in future. Also, their sponsors should be brought to book, which is their main supplies, no matter how highly placed in the society and government while the repented ones should be reoriented and rehabilitated.

f) Intelligence and intelligence sharing should be improved to nip the activities of Boko Haram and their sponsors in the bud by making use of technology and collaboration between the security agencies by resisting the 'stand-alone' operations which hitherto are practiced by some government agencies. This would maximize the use human and material resources.

\section{References}

Adams, D and Ogbonnaya, U. M. (2014). Ethnic and regional violence in Nigeria: Implication for national security. Journal of Politics and Law 7(3).

Adebayo, A. A. (2014). Implications of „Boko Harame Terrorism on National Development in Nigeria: A Critical Review. Mediterranean Journal of Social Sciences MJSS.

Adenrele, A. R. (2012). Boko Haram insurgency in Nigeria as a symptom of poverty and political alienation.November-December) in J. Hum. Soc. Sci.(JHSS), 3(5).

Adesoji, A. (2010). The Boko Haram Uprising and Islamic Revivalism in Nigeria/Die Boko-HaramUnruhenund die Wiederbelebung des Islam in Nigeria. Africa Spectrum, 95-108.

Afegbua, I.A (2010). - Conflicts and Political Instability in Nigeria: Causes, Consequences and Prospects, Journal of Social Science and Public Policy 2-10-18 
Alapiki, H. (march 12, 2015). The State and the Culture of Terrorism in Nigeria: Unveiling the Real Terrorists (Inaugural Lecture series, pp. 1-84, WorkingpaperNo.No 117).Port Harcourt: University of Port Harcourt.doi:http://web.uniport.edu.ng/files/Inaugural\%20Lectures/117\%20Inagural\%20Lecture\%20Alapiki.p df

Anyadike, N. O. (2014). Boko Haram and national security challenges in Nigeria; causes and solutions. Journal of Economics and Sustainable Development, 4(5), 1223.

Anugwom, E.E. (1997) "Ethnic Conflict and Governance in Nigeria: Lessons from the Past." Paper presented at the Nigcrian Conference on Inter-Group Conflicts, Inter-Group Wars and African Development, Dec: 3-5. Nsukka: University of Nigeria.

Armstrong, P. (2005). Popular Culture, and Lifelong Learning as Satire Adult Education Research Conference 2005 Conference Proceedings (Athens, GA) The Simpsons and Democracy Political Apathy University of Leeds, United Kingdom Kansas State

Berrebi, C. (2012). Evidence about the linkage between education, poverty and terrorism among Palestinians.Peace Economics, Peace Science and Public Policy,13(1).

Bjørgo, T. (2005). Root causes of terrorism: Myths, reality, and ways forward. London: Routledge.

Blanchard, L. P. (2011). Hearing "Boko Haram emerging threat to the U.S Homeland" Congressional Hearing Washington; Congressional Research service (2014). Nigeria's Boko Haram: Frequently Asked Questions. In CRS Report for Congress, Congressional Research Service (Vol. 10).

Braun, V., \& Clarke, V. (2006).Using thematic analysis in psychology.Qualitative research in psychology, 3(2), 77101.

Brinkel, T., \& Ait-Hida, S. (2012). Boko Haram And Jihad In Nigeria. ScientiaMilitaria- South African Journal of Military Studies Sci.Mil.,40(2).

Choi, S., \& Piazza, J. A. (2014).Internally displaced populations and suicide terrorism.Journal of Conflict Resolution, $1-33$.

Clapham, C. (2003). Terrorism in Africa: Problems of definition, history and dvelopmentSouth African Journal of International Affairs Journal Volume 10, 2003 - Issue 2

Comas, J., Shrisvatava, P., \& Martin, E. C. (2015).Terrorism as formal organization, network and social movement. Journal of Management Inquiry,24(1), 47-60. Retrieved April 06, 2015.

Dahrendorf, Ralf. (1959) Class and Class Conflict in Industrial Society. Stanford: Stanford University Press. Lutz,J. M. and Lutz,B. J.(2004).Global Terrorism Psychology Press, 2004 - Political Science - 289 pages

King, G. (2013). Restructuring the Social Sciences: Reflections from Harvard's Institute for Quantitative Social Science. PS: Political Science \& Politics APSC,47(01), 165-172.

King, G., Keohane, R. O., \&Verba, S. (1994). Designing social inquiry: Scientific inference in qualitative research.Princeton, NJ: Princeton University Press.

Kothari, C. R. (2004). Research methodology: Methods and techniques. New Delhi: New Age International (P).

Krieger, T. (2014). Great expectations and hard times: The (non-trivial) impact of education on domestic terrorism. Journal of Conflict Resolution, 1-30.

Krieger, T., \&Meierrieks, D. (2011). What causes terrorism? Public Choice, 147(12),3-27. doi:10.1007/s11127-0109601-1

Krueger, A. B. (2008). What makes a homegrown terrorist? Human capital and participation in domestic Islamic terrorist groups in the U.S.A. Economics Letters,101(3), 293-296. doi:10.1016/j.econlet.2008.09.008

Liolio, S. E. (2012). Rethinking Counterinsurgency: A case Study of Boko Haram in Nigeria. European Peace University Stadschlaining, (2006).Terrorism as Economic Warfare. Global Economy Journal,6(2). doi:10.2202/1524-5861.1113

National Bureau of Statistics Report (2012). Nigeria Poverty Profile 2010 p.16, http://issuu.com/73092/docs/mirror48

Nicholas, M. (2014). Friday Mosque Attack Killed 100 Wounded 135 in Nigeria's Kano: State governor. ReutersReporthttp://www.reuters.com/article/2014/11/29/us-nigeria-violenceidUSKCNOJD0MK 20141129

Nnoli O. (2003), "Communal Conflict and Population Displacement: An Introductory Note," in Nnoli O. (ed), Communal Conflict and Population Displacement in Nigeria, Enugu: Pan-African Centre for Research.

Olojo, A. (2013). Nigeria's Troubled North: Interrogating the Drivers of Public Support for Boko Haram. Retrieved August, 12, 2014.http://www.icct.nl/download/file/ICCT-OlojoNigerias-Troubled-North-October-2013.pdf

Onah, F.O. (2003), Human Resource Management, Enugu: Fulladu Publishing Company.

Onuoha, F. C. (2013). in Nigeria (Rep.). Aljazeera center for studies. (2014). Why do youths join Boko Haram? (Rep. No.Special Report 348).Washington DC: United States Institute of Peace. 
(2014). Publish by: Friedrich- A Danger not to Nigeria alone-Boko Haram's Transnational Reach And Regional Responses Ebert-Stiftung, Regional Office Abuja 12 Marrakesh Street, Wuse II, Abuja , Nigeria.

Ozdogan, A. (2008). Social fragmental origins of terrorism: A research note. International Journal of Comparative and Applied Criminal Justice,32(1), 111-119.

Nossiter, A. (2011). Islamic Group says it was Behind Fatal Nigeria Attacks. The New York Times.29/08/201.

Piazza, J. A. (2006). Rooted in Poverty?: Terrorism, Poor Economic Development, and Social Cleavages. Terrorism and Political Violence,18(1), 159-177. doi:10.1080/095465590944578

Piazza, J. A. (2011).Poverty, minority economic discrimination, and domestic terrorism.Journal of Peace Research,48(3), 339-353.

Richards, A. (2014). Conceptualizing terrorism. Studies in Conflict \& Terrorism,37(3), 213-236.

Richard, B. (2014). Foreign Fighters in Syria

Sánchez-Cuenca, Ignacio, Calle, Luis De la (2009) Domestic terrorism: The hidden side of political violence. Annual Review of Political Science 12: 31-49. Google Scholar, Crossref, ISI

Sanchez-Cuenca, I. (2014). Why do we know so little about terrorism? International Interactions,40(4).

Schmid, A. P. (2008). Databases on Terrorism. The Routledge Handbook of Terrorism

Research.doi:10.4324/9780203828731.ch5

Tilly, C. and S. Tarrow (2007).Contentious Politics. Boulder: Paradigm.

Umar, A. M. (2013). Nigeria and the Boko Haram sect: adopting a better strategy for resolving the crisis. Naval Postgraduate School Monterey Ca.

Ugwu, S.C. (2000), Issues in Local Government and Urban Administration in Nigeria, Enugu: Echrisi and Co.

Zenn, J. (2014). Boko Haram and the kidnapping of the Chibok schoolgirls. CTC Sentinel, 7(5), 18. https://www.ctc.usma.edu/posts/boko-haram-and-the-kidnapping-of-the-chibokschoolgirls 